Марио Лигуори*

УДК: 811.163.41: 316.647 .8

Милан Ајџановић

$811.131 .1: 316.647 .8$

Павле Секеруш

Филозофски факултет

Универзитет у Новом Саду

\title{
ПРИЛОГ О ЈЕЗИЧКИМ ПРЕДРАСУДАМА НА ИТАЛИЈАНСКОМ И СРПСКОМ ГОВОРНОМ ПОДРУЧЈУ**
}

Овај рад бави се увреженим језичким предрасудама које настају спонтано или услед језичког рефлекса код говорника на италијанском и српском говорном подручју. Пажњу смо усмерили на неколико примера: веровање да речи немају ефекта ако нису негде записане по принципу verba volant, scripta manent, убеђење да постоје логични и нелогични, супериорни и инфериорни, лепи и ружни, лаки и тешки језици, ниподаштавање дијалекта у односу на национални језик, произвољни став да наш језик пропада те да га због тога морамо бранити од утицаја страних језика и култура. У овом раду покушаћемо да се као лингвисти позабавимо набројаним темама те да их оповргнемо или барем доведемо у сумњу.

Кључне речи: предрасуда, стереотип, мит, веровање, италијански језик, српски језик.

\section{1. УВОДНЕ НАПОМЕНЕ}

1.1. Поставити питање језика значи суочити се пре свега с њему прирођеном особином: његовом непрестаном променљивошћу. Наиме, језик није постојан као стена, већ се, ма како чврсто био кодификован, непрестано мења, заузима друге форме, шири се и смањује, растеже и скупља. Говорити о језичком систему, отуд, значи говорити о предмету који се без престанка модификује, при чему се та променљивост заправо показује као неопходна за његово постојање (Downes, 1998: 233-234). Језик је непресушан извор флуидне материје која се неретко опире строгим категоризацијама, те би се он

\footnotetext{
*mario.liguori@gmail.com, ajdzanovic@ff.uns.ac.rs, psekerus@ff.uns.ac.rs

** Овај рад представља део истраживања у оквиру пројекта Стандардни српски језик (178004), који финансира Министарство просвете, науке и технолошког развоја Републике Србије.
} 
могао упоредити с каквом дивљом животињом коју је немогуће укротити: у рвању с логосом језика, чак и најдаровитији говорник на крају мора да поклекне.

Наша премиса, међутим, не налази упориште ни у италијанској ни у српској свакодневици, зато што неретко постаје незахвално пробирати поуздано језичко знање од предрасуда. У нашим срединама говорници махом не признају супериорност језика у односу на човека, напротив: за језик се неретко говори да га можемо савладати (нису ретки ни случајеви странаца који тврде да су савладали страни језик - било српски било италијански). У општеприхваћеном схватању човековог односа с језиком, наиме, човек поседује језик, те је у стању да га непогрешиво и научи. Ово распрострањено веровање (уверени смо - погрешно) сматрамо основним разлогом зашто смо се прихватили задатка да напишемо овај рад.

Горе нисмо случајно рекли да је извесно схватање језика општеприхваћено. Чињеница да говорници истовремено производе језик и размишљају о њему делује збуњујуће на оне који су жељни да се удубе у језичку проблематику. Говорници имају сопствену идеју језика, која зависи како од учесталости језичке продукције тако и од нераскидиве људске везе с говором. Памет нам је језичка, те нас је немогуће замислити без фундаменталне карактеристике говора. „Човек говори. Ми говоримо на јави и у сну. Говоримо увек, чак и онда кад се не оглашавамо ниједном речју, већ само слушамо и читамо, па и онда кад посебно нити слушамо нити читамо, већ се уместо тога бавимо некаквим послом или препуштамо доколици. Ми увек говоримо - на овај или онај начин", тврди Хајдегер (Hajdeger, 2007: 7). Ипак, пошто се знање о језику просечног говорника не заснива на научним спознајама, већ пре на конкретној употреби језика, неретко настају погрешне представе о језику. При томе, проблем није нимало баналан: с њим се, поменимо њих као нама најближе, првенствено суочавају студенти који се први пут сусрећу с појмовима о језику из уџбеника или предавања, јер ти исти појмови понекад знатно одударају од емпиријског искуства говора. Тек тада студенти почну увиђати провалију језичких предрасуда која се отвара између учења и знања.

Потреба за нашим радом произилази из нужде да оборимо или барем доведемо у сумњу језичке предрасуде које су присутне код просечних говорника те понекад, нажалост, чак и код појединих припадника образованог дела становништва. Често се превиђа да коришћење матерњег или страног језика не значи нужно и знање о језику као појави и систему. Стога различите 
предрасуде могу поткопавати сам рад на језику: перфидно се јављају у нашем окружењу, при чему се не дају лако препознати, а још мање искоренити. Поједине представе о језику прате нас од самог рођења, те се провлаче као црвена нит кроз читав наш живот - понављали су нам их прави или лажни ауторитети: поједини наши учитељи и наставници, чланови породице, пријатељи, политичари, службеници, новинари и други људи који су се нама непосредно или посредно обраћали. Стога и желимо да упозоримо на штету која због језичких предрасуда настаје на италијанском и српском говорном подручју.

\section{2. ЈЕЗИЧКЕ ПРЕДРАСУДЕ}

У овом раду ћемо, дакле, упозорити на неке језичке предрасуде с циљем да их оборимо научним аргументима. Да бисмо постигли зацртани циљ, прво морамо да дефинишемо сам појам - предрасуда, који је предмет проучавања многобројних стручњака. ${ }^{1}$ Предрасуде се најчешће одређују као рани судови, површни, дати брзоплето, некритички. „Дефинишемо као предрасуду негативан став према једној групи или ьеним члановима", 2 објашњава Тод Нелсон (Nelson, 2009: 2). По мишљењу Клауса Рота, наше представе о другима су „слике у главама које смо тек веома ретко свесно изградили по сопственом искуству, већ смо их по правилу без даљег оспоравања усвојили као деца, процесом социјализације и акултурације (васпитањем, школом, путем медија, свакодневице). Као претежно културно посредовани ставови и представе, те слике су, осим тога, често емоционално оптерећене и непосредно се тичу, како желим да покажем, емоционалне дефиниције себе и других, дакле идентитета" (Rot, 2000: 267).

Предрасуде пак могу да буду личне или колективне. Потоње се често јављају када у датој земљи делује политичка гарнитура која води дискриминаторску кампању путем језика усмерену против неке друге државе или групе људи. ${ }^{3}$ Норман Ферклаф, нимало случајно, тврди да је језик

\footnotetext{
1 За више информација о предрасудама, види Spears et al., 1997, Gardner, 1994 и Augoustinos \& Reynolds, 2001.

2 ,We define prejudice as a negative attitude toward a group or toward members of the group" (овде и на другим местима, на српски превео М. Л.).

3 Ратна тема није предмет нашег истраживања, те наш рад није место где ћемо изразити своје мишљење о смрти Југославије. Ипак, поводом троугла ,језик - рат -
} 
инструмент којим се људи служе да би владали другим људима (Fairclough, 1989: 1) те да постаје средство моћи када је носилац стереотипа и предрасуда. С тим у вези, стиче се утисак да се предрасуде учвршћују кад се у датој средини систематски јављају и понављају, што нам говори да су језик и предрасуде нераскидивно повезани.

На овом месту даћемо неке од најувреженијих језичких предрасуда с којима смо се сусретали у последњих двадесетак година на италијанском и српском говорном подручју. Наравно, наш избор је пао пре свега на белодано бизарне и погрешне ставове о језицима који су нас се највише дотакли, те ни у ком случају не сме да се сматра коначним или једино исправним. То значи да нити смо у позицији да искључимо додатне језичке предрасуде на италијанском и српском подручју нити можемо претпоставити која се све иста или друга и друкчија схватања о језику појављују у различитим срединама. Наш рад је, дакле, само подстрек за даља истраживања на изабрану тему.

\subsection{Verba volant, scripta manent.}

Премда немамо поузданих података о прецизнијем пореклу ове сентенце (према неким изворима први пут ју је употребио император Титус у једном говору у Сенату), знамо да се она у наше доба користи као средство да истакне стварну или само претпостављену пожељност и предност писане речи над говореном. Мада писана реч обезбеђује поузданост и постојаност, изговорено такође има значајно дејство на онога ко слуша. Принципи језичке прагматике умногоме указују на делотворност говорног језика. ${ }^{4}$ Замислимо, на пример, свештеника који младожењу и невесту проглашава мужем и женом: у том тренутку свештеник нешто чини, а то је језички чин. Људи нешто чине тиме што ,дају изјаву, обећају, прете, упозоре, поставе питање, дају налог итд."5 (Fairclough, 1989: 156). Пошто је човек изговорио извесне речи, може се поставити питање да ли су оне ономе коме су упућене тешко пале, натерале му сузе на очи или га пак разочарале, усрећиле, уплашиле. Језик недвосмислено утиче на унутрашње стање и понашање: тај аспекат није

национализам" на простору једне од бивших република Југославије, заинтересовани могу видети нпр. Kordić, 2010.

${ }^{4}$ У погледу језичке прагматике, види Austin, 1962.

5 ,Making a statement, making a promise, threatening, warning, asking a question, giving an order, and so on". 
секундаран, мада се олако занемарује због општеприхваћеног става о супериорности писане речи. У свету, иначе, нема трага о језику који се само пише, а да се не говори, док има много језика који се говоре, а не пишу се, подвлаче Графи и Скализе (Graffi, Scalise, 2002: 29).

Занимљиво је узети у обзир примењивање принципа verba volant, scripta manent у домену правосуђа, које у традиционалном схватању, у најбољој традицији римског права, уважава писану форму (отуда и навика да се нешто напише да би постојао доказ о датом договору/споразуму). Супротно веровању да уговори морају бити написани „црно на бело”, говорни уговори и те како постоје и важе. Тако је кад тражимо обичну кафу у кафетерији (у том случају, јасно је да се уговор спроводи разменом кафе и новца), али и у неким суштински важнијим приликама попут склапања уговора о коришћењу стана. Добар пример за то јесте италијански закон број 392 из 27. 7. 1978, ${ }^{6}$ који налаже да се правно ваљан уговор може склопити чак и усмено (GU, 1978: 5415-5428). С правног становишта, дакле, није увек тачно да речи немају конкретан ефекат. Замислимо ситуацију у којој једна особа кривично одговара зато што је некоме запретила смрћу: та ће особа кривично одговарати јер је нешто учинила запретивши другој особи. Случај се не би решио кроз призму сентенце verba volant, scripta manent, већ би по свој прилици доспео до суда.

\section{2. Постоје логични и нелогични језицฺи.}

Језичке предрасуде каткада изненађују својом истрајношћу и присутношћу у нашем животу. Поједини људи у нашем окружењу глорификују класичне језике попут старогрчког и латинског, али донекле и савремени немачки, уз објашњење да су то логични језици. Ко од нас није барем једанпут у гимназији чуо да је латински најлогичнији језик на свету? И чак и да се тај неко није сложио с таквим ставом свога наставника, због недостатка зрелости и смелости вероватно је устукнуо пред ауторитетом. Премда такве тврдње у Италији умногоме зависе од падешког система латинског језика, који делује изузетно прецизно из перспективе италијанског језика, опет није јасно због чега би један језик, макар и латински, био

\footnotetext{
6 Закон је објављен 29. 7. 1978. у Службеном гласнику Републике Италије.
} 
логичнији од других. ${ }^{7}$ Несумњиво је да сваки језик има мање или више сложен фонолошки, морфолошки и синтаксички систем који га не чини ни мање ни више логичним у односу на неке друге језике: сваки језик је систем знакова који служи за људску комуникацију, подсећа Ђузепе Берни (Berni, 1991: 13). ${ }^{8}$ У осталом, нити једно једино научно дело које смо консултовали не бележи податак да су неки језици логичнији од других или да унутар једног језика постоји само једна логика. ${ }^{9}$ Сваки језик је, назовимо га тако, организам у којем коегзистирају разне конфликтне логике. Заправо, ако бисмо језик желели с нечим да упоредимо, био би то непрегледни лавиринтски сплет. У чувеној Језичкој историји уједињене Италије, Тулио де Мауро је споменуо Витгенштајнову дефиницију да је језик „попут старог града"10 (De Mauro, 1974: 233).

Обично се ставови о супериорној логици извесног језика јављају уз један други - онај о потешкоћама у учењу истог: пошто је језик А логичнији од језика Б, самим тим је и лакши. Поводом тога, не смемо сметнути с ума нешто што се често чини - матерњи језик говорника који се сусреће са страним језиком: ако је Италијану лакше да користи шпански језик због очигледних сличности између шпанског система са италијанским, вероватно he ce, по истом принципу, једном Словаку чинити да су пољски или словеначки лакши од шпанског. ${ }^{11}$ Према томе, нема „тежих” и „лакших“ језика, већ тај субјективни став зависи од читавог низа параметара који се тичу оног ко један језик (покушава да) усваја. Иначе се ово питање покреће при учењу страног језика, зато што људи углавном превиђају да је немогуће владати било којим језиком. Тврдња „савладао сам језик X”, која се често чује, погрешна је и штетна: ако је језик ризница, ако садржи суму знања, онда није могуће да га савладамо. Ми смо, будимо искрени, тек говорници у покушају: можемо постепено напредовати у језику, направити продор до

\footnotetext{
7 Уосталом, разгранати падешки систем одлика је већине словенских језика, али им то не обезбеђује, не само у италијанској говорној заједници, статус логичних и прецизних језика.

8 Наравно, ово је општеприхваћени став језикословаца без обзира на њихову провенијенцију или теоријски приступ проучавању језика (исп. нпр. Subotić, 2005: 8).

${ }^{9}$ Види Barber, 1972 и Yule, 1985.

10 „Come una vecchia città”.

${ }^{11}$ На овом бисмо месту могли поменути и овдашњи, чини се, широко распрострањен став, нама посве непојмљив, да је италијански језик ,лак” те да је за његово усвајање потребан тек нешто већи напор.
} 
извесне тачке знања; једном речи, ми можемо усвајати поједине језичке облике и могућности, али нема изгледа да освојимо језик, ту суму различитих знања која говори кроз нас. Отуд Хајдегер (Hajdeger, 2007: 29) упозорава: „Језик говори. Човек говори ако одговара језику.”

2.3. Постоје примитивни и сложени, супериорни и инфериорни, лепи и ружни језицин.

Наравно, тврдње да постоје примитивни и сложени, супериорни и инфериорни, лепи и ружни језици нису ништа друго до пуки митови који могу бити врло опасни. Могло би се размишљати о разлозима таквих заблуда, који су углавном друштвени и политички. Тешко је замислити да се званични језик у датој земљи сматра инфериорним у односу на било који други. Та ће земља кроз процес идентитарне хомогенизације развијати позитивне аутослике, уз неутралне или негативне слике о другима, које се у имагологији дефинишу као хетерослике. С обзиром на променљивост и сложеност које су му својствене, језик се показао као непресушан извор стереотипа и предрасуда корисних ради истицања националних вредности и креирања негативних ставова о другим народима/културама, јер језик и јесте главни носилац целокупног система културних вредности једне нације. У погледу тога, ваља споменути став Паола Пројетија да је стереотип огледало у којем се сусрећу погледи посматрача и посматране културе (Proietti, 2008: 47): уколико је друштвени и политички амбијент загађен негативним хетеросликама, мишљење посматрача у односу на посматрану културу гради се путем предрасуда.

Уврежено је мишљење да се у економски и културно доминантним земљама попут, на пример, В. Британије, Француске или Немачке, користе бољи, то јест, наводно, богатији језици. Истина, језик може допринети развоју ако га сви грађани разумеју, док може представљати проблем уколико у једној земљи различити језици лоше коегзистирају у смислу да је свака језичка група изолована у односу на другу. С друге стране, степен развитка једног друштва, не само техничко-технолошког, нужно доводи до богаћења лексике језика. Не можемо искључити ни то да економско стање може донекле утицати на језичке навике, али економски и језички развој нису ни у каквој директној вези која може да проузрокује пропаст језика: енглески, француски и немачки не можемо прогласити „бољим језицима” (ма шта то тачно значило), само 
зато што се они говоре у богатим срединама. Тако, на пример, „енглески језик није посебан кад је реч о економском развоју и расту"12, тврде Арканд и Грин, који су истраживали дату тему (Arcand \& Grin, 2013: 262). Сличан проблем јавља се унутар граница једне земље ако у њој има богатијих и сиромашнијих крајева: неретко се рађају предрасуде које се тичу школства, образовања и, на крају крајева, самог идиома који се у тим (микро)регијама користи. Италија је у погледу тога школски пример: за многе Италијане и странце сасвим је легитимно сматрати да се на северу Полуострва говори прави италијански језик, док се на југу говори лоша или простија верзија која само личи на стандард. Наравно, то зависи од фасцинације бољим економским стањем са севера Италије, али и од језичког незнања и површности. Све је то у непосредној вези с предрасудама и стереотипима, које је Клаус Рот дефинисао као „прилично стабилне свакодневне категоризације, типизације окружења” (Rot, 2000: 260).

Поводом претпостављене разлике између супериорних и инфериорних језика, у Италији се у неким контекстима подразумева домаћа супериорност: италијански се сматра најлепшим језиком на свету, језиком љубави и других племенитих осећања. ${ }^{13}$ На овом месту не поричемо пријатност звука италијанских речи и реченица због ритма, прозодије и уравнотежене комбинације сугласника и самогласника. Италијански остаје језик опере и чувених песама, али тврдња да је реч о најлепшем језику естетска је процена која не садржи меру објективности: дефинисање лепог и ружног сувише је субјективно да би се уважавало у лингвистичком дискурсу. Уосталом, зар се за француски не говори да је елегантан? Зар немачки не важи за језик филозофије? С једне стране, имамо науку која предност даје систематском знању и рационалности, док, с друге, стереотипе и предрасуде. Иако је Карло $\mathrm{V}$ Хабзбуршки рекао да француски користи с мушкарцима, италијански са женама, а немачки с коњима (Graffi, Scalise, 2002: 49), његова изјава може да изазове само благи подсмех у науци. Све док буду живели стереотипи о бучним, енергичним, симпатичним Италијанима, тешко ће просечни говорници успевати да се приближе научном разумевању језика.

\footnotetext{
12 „English is not 'special' in terms of economic development or growth”.

${ }^{13}$ У датој средини јављају се прилози који, без обзира на интенције аутора, од самог наслова указују на претпостављену супериорност италијанског језика (види Andreoni, 2017).
} 
Што се српског језика тиче, како га оцењују сами Срби, а како они којима тај језик није матерњи? Наравно, као и у много чему другом, и овде су присутни посве опречни ставови, при чему се крајње позитивни и крајње негативни доживљаји српског језика и (знатно чешће) његових носилаца могу наћи и међу Србима и међу онима који то нису. С једне стране, српски се доживљава као својеврстан небески или барем најстарији језик, ${ }^{14}$ чији почеци писмености сежу у далеку прошлост и тзв. винчанско писмо, што му даје недвосмислено преимућство у односу на друге језике. ${ }^{15}$ То се додатно потцртава чињеницом да је српски језик, због своје разуђене морфологије и четвороакценатског система, безмало неосвојива тврђава за странце, док је, насупрот томе, његов фонолошки ортографски проседе најближи идеалном правопису. С друге стране, у домаћем и страном огледалу Срби и њихов језик могу да представљају парадигму за дивље, примитивне Балканце којима су насиље, рат и просташтво неизоставни елементи. ${ }^{16}$ Очито и у овом случају, као у многочему другом, све зависи од посматрача, креатора афирмативних и негативних аутослика и хетерослика.

\section{4. Језик је супериоран у односу на дијалекат.}

Ово је једна од најувреженијих језичких предрасуда, нарочито у Италији, где је писани тоскански дијалекат из литерарних, друштвених, историјских и политичких разлога испливао међу разним дијалектима и постао национални језик. Језик и дијалекат немају исти статус, али разлика између њих није одређена пуким језичким критеријумима. Дијалекти у Италији, наравно, нису тек скрајнуте верзије тосканског: „Некада су романски језици били дијалекти латинског који су постигли статус језика под утицајем времена и географије", 17 констатује Едвардс (Edwards, 1985: 22). Његова изјава потврђује чињеницу да су различити језички обрасци на Апенинском полуострву посве самостални: из лингвистичког угла, сваки дијалекат је потпуно легитиман систем (Edwards, 1985: 132). Међутим, невоља лежи у томе што просечни говорници не схватају језик као систем знакова који

14 Чувена српска изрека „говори српски да те цео свет разуме” неретко се код псеудолингвиста и лаика узима као потврда оваквог става.

${ }^{15}$ Исп. нпр. Milosavljević, 2002.

${ }^{16}$ О овоме в. више у Bakić, 1999.

17 „The Romance languages were once dialects of Latin which, under the influence of time and geography, came to achieve language status". 
омогућује људску комуникацију, већ се заустављају на пуком емпиријском опажању разлика међу различитим облицима националног језика и дијалеката. Но такве процене су непоправљиво засноване на импровизацији. Чини се да је Ђанлуиђи Гаспари у праву када истиче да сами говорници дијалекта сматрају да је национални језик супериоран (Gaspari, 1972: 153), до чега је дошло због многих десетлећа запостављања и демонизације дијалеката, што је у италијанском језичком подручју факат, тврди Манлио Кортелацо (Cortelazzo, 2002: XXV). Велику улогу у изразитом дуализму језик-дијалекат пак играју поједини културни и национални посленици: тежња ка ниподаштавању дијалеката у Италији постала је константа и код културне елите и код лингвиста (Camilleri \& De Mauro, 2017: 23). Негативни ставови о дијалектима зависе од традиционалних предрасуда, јер се обично прећуткује

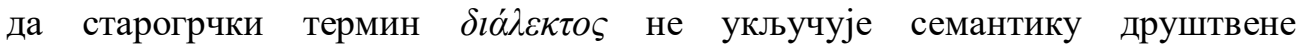
инфериорности говорника, те да је тек у италијанској ренесанси тај термин сведен у односу на термин језик, као што је то објаснио Марио Алинеи (Alinei, 1981: 156-161).

Поводом фамозне дихотомије језик-дијалекат можемо приметити да се само њено постојање може сматрати последицом нетачних ставова о језику. Стереотипи и предрасуде настају на самом почетку расправе, чим дође до ње: ако сваки говор у нашем животу заузима природно место које му припада с обзиром на нашу личну историју, онда нема места супротстављању. Кад човек научи облике другог језика, његов први језик не нестаје, јер појава другог језика не угрожава нужно први; стога је погрешно, примера ради, негирати дијалекат да би се учио италијански, зато што дијалекатско благо уноси у италијански језик садржаје који му иначе недостају, држи Вера Гено (Gheno, 2016: 39)

Предрасуде о дијалектима тичу се наводног недостатка писане продукције, што је у италијанском контексту бесмислица (Beccaria, 1975: 1), будући да су нека капитална дела из XX века настала захваљујући тим истим дијалектима које многи оспоравају: ни Карло Емилио Гада ни Пјер Паоло Пазолини не би изнедрили своја дела без кључног доприноса дијалекатског блага. ${ }^{18}$ Истина, дијалекат је у употреби на мањој територији, мање је познат, те може да садржи лексичке недостатке (Graffi, Scalise, 2002: 49). Еминентни лингвист Тулио де Мауро упозорава да дијалекат којі има амбицију да постане национални језик мора да садржи велику унутрашњу сложеност и

${ }^{18}$ Види Gadda, 1957 и Pasolini, 1955. 
широку лепезу стилова, од ниског до највишег степена формалности и регистра (Camilleri, De Mauro, 2017: 25-26).

Чињеница је да српска дијалекатска мапа није ни изблиза разуђена као италијанска, што је утемељитељима српског стандардног језика и омогућило да се приликом бирања дијалеката погодних за установљавање стандардног идиома као кључни критеријуми наметну не само они који се тичу културолошког престижа већ и оног демографског и географског. Будући да су за основицу стандардног идиома узета два најраспрострањенија дијалекта, данас највећи број изворних говорника српског језика говори идиомом блиским стандарду, што у крајњем за последицу има релативно благонаклон став према дијалектима. Ипак, ни српска јавност, па чак ни стручна и културна елита, није посве имуна на ниподаштавање дијалеката, ${ }^{19}$ при чему су поједини рецентнији покушаји својеврсне језичке хегемонизације били усмерени не само према дијалектима већ и, што је заиста реткост у европским и светским оквирима, једној од две изговорне норме самог стандардног језика - оној (и)јекавској. Када се овоме дода и проблем диграфије присутне у српском језику те појаве нових стандардних идиома заснованих на новоштокавској основици јасно је да пред српским лингвистима тек предстоје немали изазови у суочавању с односом према различитим појавним облицима једног истог језика. ${ }^{20}$

\section{5. Нужно је бранити нациионални језик од утицаја других језика.}

Мит о пропадању националног језика под утицајем страних кристалише се, нажалост, као једна од широко раширених појава још у XX веку. Идеја да држава, помоћу националних културних институција, може битно променити природни ток језика, као и да развој тог истог језика не зависи од употребе, крије националистичке и идентитарне мотиве. Сам став да нејезички фактор има моћ да одреди природу језика под плаштом националног идентитета не може рачунати на научно покриће, мада то није

19 Овакви притисци довели су до различитих реакција, међу којима је у широј јавности нарочиту пажњу привукла она академика Д. Михаиловића.

${ }^{20}$ Са знатно већим проблемима који се тичу односа између стандардног језика и дијалекта, али сада и наречја, срећу се кроатистика и кроатисти. Ипак, да је могућ друкчији, неконзервативни приступ статусу дијалекта, посве друкчији од преовлађујућег, види се у ставовима појединих хрватских лингвиста, међу којима се нарочито истиче Мате Каповић (исп. нпр. Kapović, 2006). 
спречило националне културне установе да агресивно делују у области језика као идентитарног знака par excellence (Gheno, 2016: 27). Сњежана Кордић је тим поводом упозорила да се у националистичком контексту „прави паника о пропасти језика, нације, културе пред страном инвазијом” (Kordić, 2010: 27). Силвија Моргана је набројила примере из Мусолинијеве епохе, када је фашистички режим објавио језички рат страним речима и изразима (Morgana, 2009: 106-107), али је такође скренула пажњу на чињеницу да количина енглеских термина који се најчешће оптужују због којекаквих „напада” на италијански језик, данас остаје занемарљива у свакодневној комуникацији (2009: 109). Ми смо, додуше, у италијанској говорној средини уочили сасвим неоправдану употребу туђица у штампи и нарочито на телевизији, где се обично појављује језик који није у употреби код већине становништва. Стање није много другачије у Србији, где, да наведемо само један баналан пример, конобари често питају да ли ће муштерије платити кешом, без обзира на постојање изворне речи готовина. Такви случајеви могу пре да се припишу помодарству или незнању говорника, проистеклим из преовлађујућег духа времена, него некаквој еволуцији или напретку културе.

Ипак, без обзира на научну неутемељеност тврдњи о неопходној одбрани језика од спољашњих фактора, често чујемо да се националном језику црно пише због тих утицаја са стране. Истовремено, ретко где се истичу рогобатна излагања неких јавних говорника који, рецимо то тако, тлаче матерњи језик у жељи да свој израз мистификују пред простим пуком. По свему судећи, култура говора није главна преокупација у јавном говору. Језик политике, администрације и штампе служи као најбољи пример за то. Поводом језика администрације, Душка Кликовац сматра да је бирократски језик „обликован према својој основној сврси - манипулацији људима” (Klikovac, 2008: 7). Тамо где се језик жртвује на олтару моћи, циљ накарадне комуникације није ни разумевање ни лепота израза већ управо супротно неразумевање. Понекад нам се и чини да поједини службеници све чине како грађани не би схватили (пре)поруку. У том домену ни штампа нема много разлога за тријумфализам: „Савремена штампа у Србији све чешће усваја службени фразерски језик политичких и економских моћника”, тврди Добривоје Станојевић (Stanojević, 2013: 34). Наведени ставови упућују на мит да изворни говорници одлично владају матерњим језиком. Истина је ипак мало мрачнија: изворни говорници се у бити крећу у матерњем језику као странци. Ако с балканске пређемо на италијанску реалност, погодиће нас речи Тулија де Маура, према којем само двадесетак посто Италијана може да се 
хвали основним компетенцијама у читању и писању без којих човек не може да се суочи с изазовима савременог друштва (De Mauro, 2008: 7-13). Толико о претпоставци да изворни говорници владају матерњим језиком.

\section{3. ЗАКљУЧАК}

У овом раду анализирали смо неке од најувреженијих предрасуда које се односе на језик у намери да их оборимо аргументима. Пошто је језик један од феномена који подлежу непрестаној продукцији и неизбежан пратилац скоро сваке сфере испољавања људског генија, говорници природно нагињу ка извесној идеји о њему, при чему развијају ставове и/или стереотипе који нису научно утемељени, већ зависе од њиховог субјективног говорног искуства. Међутим и наравно, пука употреба не може бити објективни критеријум да бисмо изградили мишљење о датом феномену.

По свој прилици, језик трпи појаву разних ванјезичких фактора који непрестано врше притисак на њега: идентитарне и националне политике, историја и традиција, интереси економских моћника и динамике савременог друштва - све се то прелама кроз језик стварајући за последицу својеврстан нетранспарентни конгломерат. Стога у мноштву интереса, језичких манипулација и пуког незнања, постаје тешко „разабрати се у плетиву”.

Током нашег рада било је нужно навести неколико примера типичних језичких предрасуда које доводе у питање у лингвистици признате чињенице. Одабрали смо да то буду веровање да језик подразумева последице једино ако је написан „црно на бело”, мит о логичним језицима, претпостављена супериорност и/или лепота неких изабраних језика науштрб других, подређен положај дијалеката у односу на језик, као и мит о угроженом језику који пропада и који се мора штитити од спољних напада. Није нимало случајно да су предрасуде и митови које смо узели у обзир присутни у земљама у којима се крећемо јер на неки начин представљају универзални став човека према своме и туђем, у којем се неретко прво изједначава с добрим и пожељним, а друго с непожељним и лошим. Наравно, то нису једини контроверзни ставови о језицима, те наш рад служи само као подстрек, као база за истраживање других погрешних или барем бизарних веровања о језицима.

За крај, осећамо потребу да подсетимо на то да су језичке политике у једном друштву важан показатељ доминантних снага које га покрећу и праваца у којима та друштва желе да се развијају, индикатори прокламованих и непрокламованих циљева једне заједнице, те и отуд важност коју придајемо научном приступу питањима језика. 
Mario Liguori, Milan Ajdžanović, Pavle Sekeruš

\section{A CONTRIBUTION TO THE LINGUISTIC PREJUDICE ON ITALIAN AND SERBIAN SPEAKING AREAS}

\section{Summary}

This paper deals with the entrenched linguistic prejudices which occur both in Italy and Serbia, sometimes even in academic contexts. Our analysis took into account, for instance, the belief that words do not have an effect if they are not written down, according to the Latin principle verba volant, scripta manent. We analysed linguistic stereotypes, myths and prejudices, such as the belief that there are logical and illogical, superior and inferior, beautiful and ugly, easy and difficult to learn languages. Eventually, we examined the discrimination of dialects compared with national languages and discussed the belief that our language is destined to disappear if it is not defended from the influences of foreign languages and cultures.

Key words: prejudice, stereotype, myth, belief, Italian, Serbian.

\section{ИЗВОРИ}

GU, 1978: Gazzetta Ufficiale della Repubblica Italiana. N. 211, 29-7-1978

\section{ЛИТЕРАТУРА}

Alinei, M. (1981). "Dialetto": un concetto rinascimentale fiorentino. Storia e analisi. Quaderni di Semantica, 1, Alessandria, 147-173.

Andreoni, A. (2017). Ama l'italiano: segreti e meraviglie della lingua più bella. Milano: Piemme.

Arcand, J. \& Grin, F. (2013). Language in economic development: Is English special and is linguistic fragmentation bad?, In: Erling, E. \& Sergeant, P. (edit.) (2013). English and Development. Policy, Pedagogy and Globalization. Bristol: Multilingual Matters. 243-266.

Augoustinos, M. \& Reynolds, K. (2001). Understanding prejudice, racism, and social conflict. London-Thousand Oaks-New Delhi: SAGE.

Austin, J. (1962). How to Do Things with Words. Oxford: Clarendon Press.

Barber, C. L. (1972). The Story of Language. London: Pan Books.

Beccaria, G. L. (1975). Letteratura e dialetto. Bologna: Zanichelli.

Bakić, J. (1999). Stereotipi o Srbima u javnostima pojedinih zapadnih nacija: nova teorijska zapažanja. Nova srpska politička misao, 6, 1-2, 27-55. (štampano ćirilicom) 
Berni, G. (1991). La lingua come sistema: ipotesi didattica di grammatica strutturale della lingua italiana. Pisa: Giardini.

Camilleri, A. \& De Mauro, T. (2017). La lingua batte dove il dente duole. RomaBari: Laterza.

Cortelazzo M. (2002). I dialetti italiani, In: Cortelazzo, M. - Marcato, C. - De Blasi, N. \& Clivio, G. P. (a cura di). I dialetti italiani.Torino: UTET. XXIII-XXX.

De Mauro, T. (1974). Storia linguistica dell'Italia unita. Roma-Bari: Laterza.

De Mauro, T. (2008). Analfabeti d'Italia. Internazionale. 7-13 marzo. Roma. 7-13.

Downes, W. (1998). Language and Society. Cambridge: Cambridge University Press.

Edwards, J. (1985). Languae, Society, and Identity. Oxford: Basil Blackwell.

Fairclough, N. (1989). Language and Power. London-New York: Longman.

Gadda, C. E. (1957). Quer pasticciaccio brutto de via Merulana. Milano: Garzanti.

Gardner, R. C. (2014). Stereotypes as consensual beliefs, In: M. P. Zanna \& J. M. Olson (Eds.), The Psychology od Prejudice: The Ontario Symposium (vol. 7). Hillsdale-New York: Erlbaum. 1-31.

Gaspari, G. (1972). Intorno al friulano, sulla questione ,lingua-dialetto”. Atti del Convegno per gli Studi Dialettali Italiani (Lecce, 28 settembre - 1 Ottobre 1972). Pisa: Pacini. 153-168.

Gheno, V. (2016). Guida pratica all'italiano scritto (senza diventare grammarnazi). Firenze: Franco Cesati Editore.

Graffi, G. \& Scalise, S. (2002). Le lingue e il linguaggio: introduzione alla linguistica. Bologna: Il Mulino.

Hajdeger, M. (2007). Na putu k jeziku. Beograd: Fedon.

Kapović, M. (2006). Dijalekti, standard i sociolingvistički aktivizam, U: J. Granić (ur.), Jezik i mediji - jedan jezik : više svjetova. Zagreb-Split: HDPL. 375383.

Klikovac, D. (2008). Jezik i moć. Beograd: Biblioteka XX vek.

Kordić, S. (2010). Jezik i nacionalizam. Zagreb: Durieux.

Milosavljević, O. (2002). U tradiciji nacionalizma ili stereotipi srpskih intelektualaca XX veka o ,nama” $i$,,drugima”. Beograd: Helsinški odbor za ljudska prava u Srbiji.

Morgana, S. (2009). Breve storia della lingua italiana. Roma: Carocci.

Nelson, T. D. (2009). Handbook of prejudice, stereotyping, and discrimination. New York-Hove: Psychology Press, Taylor \& Francis Group.

Pasolini, P. P. (1955). Ragazzi di vita. Milano: Garzanti. 
Proietti, P. (2008). Specchi del letterario: l'imagologia. Palermo: Sellerio.

Rot, K. (2000). Slike u glavama. Beograd: Biblioteka XX vek.

Spears et al., 1997: R. Spears et al (1997). The social psychology of stereotyping and group life. Oxford-Cambridge: Blackwell.

Stanojević, D. (2013). Palanački klišei i štampa u Srbiji. Medijski dijalozi, VI, 16, Podgorica, 31-44.

Subotić, Lj. (2005). Ortoepska i ortografska norma standardnog srpskog jezika. Novi Sad: Filozofski fakultet.

Yule, G. (1985). The Study of Language: An Introduction. Cambridge: Cambridge University Press. 